\title{
PERAN HAKIM PERADILAN TERHADAP PARA PENCARI KEADILAN
}

\author{
Akhmad Shodikin \\ Fakultas Syariah dan Ekonomi Islam \\ IAIN Syekh Nurjati Cirebon \\ J1. Perjuangan By Pass Sunyaragi Cirebon \\ Email: shodikin73@gmail.com
}

\begin{abstract}
Abstrak
Keadilan merupakan tonggak dari sebuah perkara hukum. Dalam beberapa penanganan kasus hukum yang terjadi di tanah air, seringkali mencuat menjadi bahan perbincangan publik karena putusan pengadilan dianggap mengabaikan nilai-nilai keadilan yang semestinya dirasakan oleh masyarakat dan pencari keadilan. Proses hukum di lingkungan peradilan Indonesia hingga saat ini dianggap belum sepenuhnya mencerminkan nilai-nilai keadilan yang sesungguhnya, keadilan seolah menjadi "barang mahal" yang jauh dari jangkuan masyarakat. Penyusun memaparkan tentang bagaimana peran hakim mencari keadilan substantif untuk memutus perkara peradilan serta tinjuan hukum Positif dan hukum Islam terhadap prosedur hakim dalam mencari keadilan subatantif.
\end{abstract}

Kata Kunci: Peranan Hakim, Peradilan, dan Keadilan

\begin{abstract}
Justice is a milestone of a lawsuit. In some handling of legal cases occurring in the homeland, it is often sticking to the subject of public discussion because the court's decision is considered to ignore the values of justice that should be felt by the public and seekers of justice. The legal process in the Indonesian judiciary to date has not yet fully reflected the true values of justice, justice seems to be "expensive goods" far from the reach of society. The authors describe how the role of the judge seeks substantive justice for deciding judicial matters as well as Positive legal review and Islamic law against judicial procedures in seeking substantive justice.
\end{abstract}

Keywords: The Role of Judges, Justice, and Justice 



\section{A. Pendahuluan}

Kehidupan manusia dalam melakukan interaksi sosialnya selalu akan berpatokan pada norma atau tatanan hukum yang berbeda dalam masyarakat. Manakala manusia berinteraksi, tidak berjalan dalam kerangka norma atau tatanan yang ada, maka akan terjadi bias dalam proses interaksi itu. Sebab tidak dapat dipungkiri manusia memiliki kecenderungan untuk menyimpang dari norma dan tatana yang ada, karena terpengaruh oleh adanya hawa nafsu yang tidak terkendali. Hal yang sama juga akan berlaku bagi yang namanya. ${ }^{1}$

Keadilan secara umum diartikan sebagai perbuatan atau perlakuan yang adil. Sementara adil adalah tidak berat sebelah, tidak memihak dan berpihak kepada yang benar. Keadilan menurut kajian filsafat adalah apabila dipenuhi dua prinsip, yaitu: pertama tidak merugikan seseorang dan kedua, perlakuan kepada tiap-tiap manusia apa yang menjadi haknya. Jika kedua prinsip ini dapat dipenuhi barulah itu dikatakan adil. Eksistensi hukum sangat diperlukan dalam mengatur

1 Ahmad Rifai, Penemuan Hukum oleh Hakim dalam Perspektif Hukum Progresif , (Jakarta:Sinar Grafika, 2010), hlm 13 kehidupan manusia, tanpa hukum, kehidupan manusia akan liar, siapa yang kuat dialah yang menang, tujuan hukum untuk melindungi kepentingan manusia dalam mempertahankan hak dan kewajiban. $^{2}$

Pada praktiknya, pemaknaan keadilan dalam penanganan sengketa-sengketa hukum ternyata masih debatable. Banyak pihak merasakan dan menilai bahwa lembaga pengadilan kurang adil karena terlalu syarat dengan prosedur, formalistis, kaku, dan lamban dalam memberikan putusan terhadap suatu sengketa. Agaknya faktor tersebut tidak lepas dari cara pandang hakim terhadap hukum yang amat kaku dan normatifprosedural dalam melakukan konkretisasi hukum. Sedangkan hakim mampu menjadi living interpretator yang mampu menangkap semangat keadilan dalam masyarakat dan tidak terbelenggu oleh kekakuan normatif-prosedural yang ada dalam suatu peraturan perundang-undangan, karena hakim bukan lagi sebagai corong undangundang. Artinya, hakim dituntut

\footnotetext{
2 Mertokusumo Sudikno, "Metode Penemuan Hukum" (Yogyakarta:UII Press, 2007), hlm 3
} 
untuk memiliki keberanian mengambil keputusan yang berbeda dengan ketentuan normatif undangundang, sehingga keadilan substansial selalu saja sulit diwujudkan melalui putusan hakim pengadilan, karena hakim dan lembaga pengadilan hanya akan memberikan keadilan formal.

Keadilan yang diberikan sesuai dengan aturan-aturan hukum substantif, dengan tanpa melihat kesalahan-kesalahan prosedural yang tidak berpengaruh pada hak-hak substantif Penggugat. Ini berarti bahwa apa yang secara formalprosedural benar bisa saja disalahkan secara materiil dan substansinya melanggar keadilan. Demikian sebaliknya, apa yang secara formal salah bisa saja dibenarkan jika secara materiil dan substansinya sudah cukup adil (hakim dapat menoleransi pelanggaran procedural asalkan tidak melanggar substansi keadilan). Dengan kata lain, keadilan substantif bukan berarti hakim harus selalu mengabaikan bunyi undang-undang. Melainkan, dengan keadilan substantif berarti hakim bisa mengabaikan undang-undang yang tidak memberi rasa keadilan, tetapi tetap berpedoman pada formal procedural undang-undang yang sudah memberi rasa keadilan sekaligus menjamin kepastian hukum.

Peradilan sebagai wujud implementasi hukum dalam sebuah system hukum nasional membutuhkan perangkat hukum memadai, sehingga segala keputusannya dapat memberi keadilan bagi pencari hukum. Meskipun tuntutan keadilan hukum dari masyarakat sangat tinggi ditambah dengan akumulasi problematika kehidupan yang sangat kompleks, namun perangkat hukum untuk tercapainya keadilan dalam hukum nampaknnya terutama masih sangat minim. Hal demikian terdapat pada materi Undang-undang yang masih sangat memungkinkan bagi para pelanggar hukum untuk lolos dari jeratan hukum. Hakim dan hakim konstitusi wajib menggali, mengikuti, dan memahami nilainilai hukum dan rasa keadilan yang hidup dalam masyarakat. ${ }^{3}$

Pada dasarnya tugas hakim adalah memberi keputusan dalam setiap perkara atau konflik yang dihadapkan kepadanya, menetapkan hal-hal seperti hubungan hukum, nilai hukum dari perilaku, serta

3 Lihat, Pasal 5 Undang-undang No.48 Tahun 2009 tentang Kekuasaan Kehakiman 
kedudukan hukum pihak-pihak yang terlibat dalam suatu perkara, sehingga untuk dapat menyelesaikan perselisihan atau konflik secara imparsial berdasarkan hukum yang berlaku, maka hakim harus selalu mandiri dan bebas dari pengaruh pihak manapun, terutama dalam mengambil suatu keputusan. Hakim adalah pejabat peradilan negara yang diberi wewenang oleh undangundang untuk mengadili suatu perkara yang dihadapkan kepadanya. ${ }^{4}$ Adapun pengertian dari mengadili itu adalah serangkaian tindakan hukum untuk menerima, memeriksa dan memutuskan suatu perkara berdasarkan asas bebas, jujur, dan tidak memihak di sidang pengadilan. $^{5}$

\section{Berdasarkan}

ketentuan

tersebut di atas, maka hakim dipaksa atau wajib turut serta menentukan mana yang merupakan hukum dan mana yang tidak. Bilamana undangundang tidak mengatur suatu perkara, maka hakim harus bertindak atas inisiatif sendiri untuk menemukan dan menggali nilai-nilai hukum yang tidak tertulis yang hidup di kalangan rakyat (living law).

4 Ahmad Rifai, Penemuan Hukum oleh Hakim dalam Perspektif Hukum Progresif (Jakarta:Sinar Grafika, 2010), hlm 3

${ }^{5}$ Lihat, Pasal 1 butir (9) KUHAP
Untuk itu, ia harus terjun ke tengahtengah masyarakat untuk mengenal, merasakan dan mampu menyelami perasaan hukum dan rasa keadilan yang hidup dalam masyarakat.

\section{B. Hakim}

\section{Pengertian Hakim}

Hakim berasal dari kata

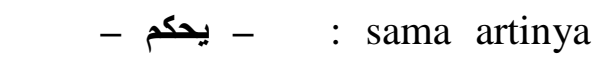
dengan qodh'i yang berasal dari kata قض - يقضى - قا ضrtinya memutus. Sedangkan menurut bahasa adalah orang yang bijaksana atau orang yang memutuskan perkara dan menetapkannya. ${ }^{6} \quad$ Adapun pengertian menurut syar'a yaitu orang yang diangkat oleh kepala negara untuk menjadi hakim dalam menyelesaikan gugatan, perselisihan-perselisihan dalam bidang hukum perdata oleh karena penguasa sendiri tidak dapat menyelesaikan tugas peradilan, ${ }^{7}$ sebagaimana Nabi Muhammad SAW telah mengangkat qoth'i untuk bertugas menyelesaikan sengketa di antara manusia di tempat-tempat yang jauh,

\footnotetext{
${ }^{6}$ Muhammad Salam Madkur, Al-Qada Fil Islam, (Ttp : tt) hlm. 11.

7 Tengku Muhammad Hasbi Ash Sidiqi, Peradilan dan Hukum Acara Islam cet. ke-1, Semarang : PT Pustaka Rizki Putera, 1997), hlm. 39.
} 
sebagaimana ia telah

melimpahkan wewenang ini pada sahabatnya. ${ }^{8}$ Hal ini terjadi pada sahabat dan terus berlanjut pada Bani Umayah dan Bani Abbasiah, diakibatkan dari semakin luasnya wilayah Islam dan kompleknya masalah yang terjadi pada masyarakat, sehingga diperlukan hakim-hakim untuk menyelesaikan perkara yang terjadi.

Hakim sendiri adalah pejabat peradilan negara yang diberi wewenang oleh undangundang untuk mengadili. ${ }^{9}$ Sedangkan dalam Undang-undang kekuasaan kehakiman adalah penegak hukum dan keadilan wajib menggali, mengikuti dan memahami nilai-nilai hukum yang hidup di masyarakat. ${ }^{10}$ Hakim adalah sebagai pejabat Negara yang diangkat oleh kepala Negara sebagai penegak hukum dan

${ }^{8}$ Muhammad Salam Madkur, Al-Qada Fil Islam., hlm. 11.

9 Mengadili diartikan sebagai serangkaian tindakan hakim untuk menerima, memeriksa dan memutus perkara berdasarkan asas bebas, jujur dan tidak memihak di sidang pengadilan dalam hal dan menurut tata cara yang diatur dalam undang-undang.lihat Undang-undang Nomor 8 Tahun 1981 Tentang Hukum Acara Pidana (KUHAP) Pasal 1 (1)

${ }^{10}$ Ketentuan ini dimaksudkan agar putusan hakim sesuai dengan hukum dan rasa keadilan masyarakat. lihat Undang-undang Nomor 4 Tahun 2004 Tentang Kekuasaan Kehakiman beserta penjelasannya, Pasal 28 Ayat (1) keadilan yang diharapkan dapat menyelesaikan permasalahan yang telah diembannya menurut Undang-undang yang berlaku.

Hakim merupakan unsur utama di dalam pengadilan. ${ }^{11}$ Bahkan ia "identik" dengan pengadilan itu sendiri. Kebebasa kekuasaan kehakiman seringkali diidentikkan dengan kebebasan hakim. Demikian halnya, keputusan pengadilan diidentikkan dengan keputusan hakim. Oleh karena itu, pencapaian penegakkan hukum dan keadilan terletak pada kemampuan dan kearifan hakim dalam merumuskan keputusan yang mencerminkan keadilan. ${ }^{12}$

Adapun pengertian qad'a sendiri ada beberapa makna yaitu: $^{13}$

a. Menyelesaikan seperti dalam Firman Allah:

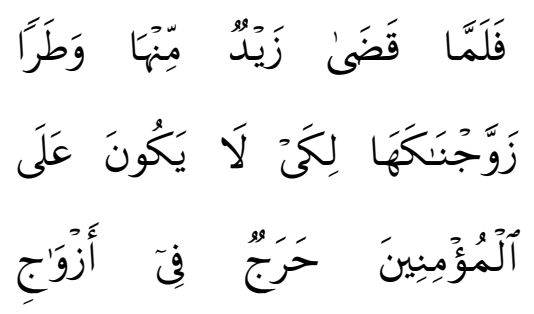

11 Cik Hasan Bisri, Peradilan Agama di Indonesia, Cet. ke-2 (Jakarta: PT Raja Grafindo Persada, 1998), hlm. 180.

${ }^{12}$ Cik Hasan Bisri,... hal 180.

13 Tengku Muhammad Hasbi ash Shidiqi, Peradilan., hlm. 33-34. 


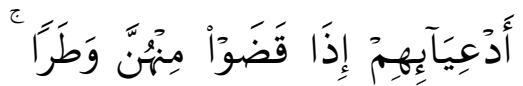

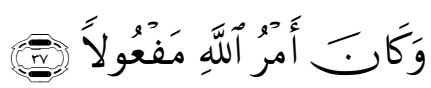

"Maka tatkala Zaid telah mengakhiri keperluan

terhadap Istrinya

(menceraikannya), Kami

kawinkan kamu dengan dia supaya tidak ada keberatan bagi orang mukmin untuk (mengawini) isteri-isteri anakanak angkat mereka, apabila anak-anak angkat itu telah menyelesaikan keperluannya daripada isterinya. dan adalah ketetapan Allah itu pasti terjadi" . (Q.S. Al-Ahzab: 37)

b. Menunaikan dalam firman Allah

فَإِذَا قُضِيَتِ ألصَّلَوَة فَاْنتَشُرُواْ فِى

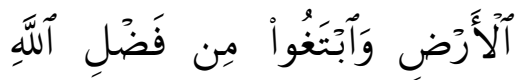

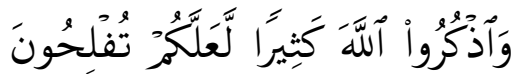

"Apabila telah ditunaikan shalat, Maka bertebaranlah kamu di muka bumi; dan carilah karunia Allah dan ingatlah Allah banyak-banyak supaya kamu beruntung". (Q.S. Al-J umu'ah: 10)

c. Menghalangi atau mencegah yang artinya hakim bisa melaksanakan amar ma'ruf nahi munkar, menolong yang teraniaya dan menolak kezoliman yang merupakan kewajiban.
2. Dasar dan Syarat

\section{Pengangkatan Hakim}

Lembaga peradilan sebagai lembaga Negara yang ditugasi menerapkan hukum (Izhar Al Hukm) terhadap perkaraperkara yang berkaitan dengan hukum dan adanya hakim sebagai pelaksana dari Undang-undang Nomor 4 Tahun 2004 Tentang Pokok-pokok Kekuasaan Kehakiman, ketetapan Majelis Permusyawarakatan Indonesia Nomor X/MPR/1998 yang menyatakan perlunya reformasi di bidang hukum untuk penanggulangan dibidang hukum dan ketetapan Majlis Permusyawatan Rakyat Nomor III/MPR/1978 Tentang Hubungan Tata Kerja Lembaga Tinggi Negara.

Dalam al-Quran di jelaskan:

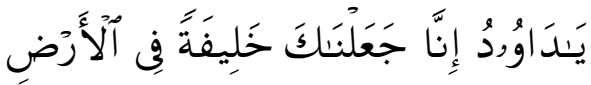

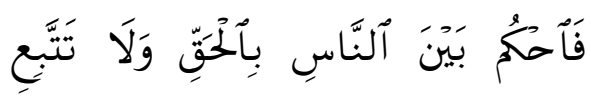

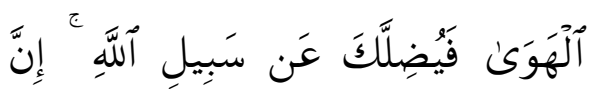

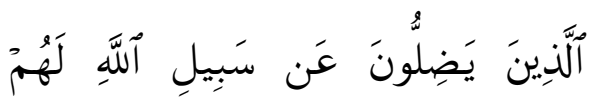

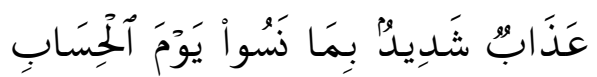


"Hai Daud, Sesungguhnya Kami menjadikan kamu khalifah (penguasa) di muka bumi, Maka berilah keputusan (perkara) di antara manusia dengan adil dan janganlah kamu mengikuti hawa nafsu, karena ia akan menyesatkan kamu dari jalan Allah. Sesungguhnya orang-orang yang sesat darin jalan Allah akan mendapat azab yang berat, karena mereka melupakan hari perhitungan". (Q.S. Shaad: 26)

Dalam ayat lain di sebutkan:

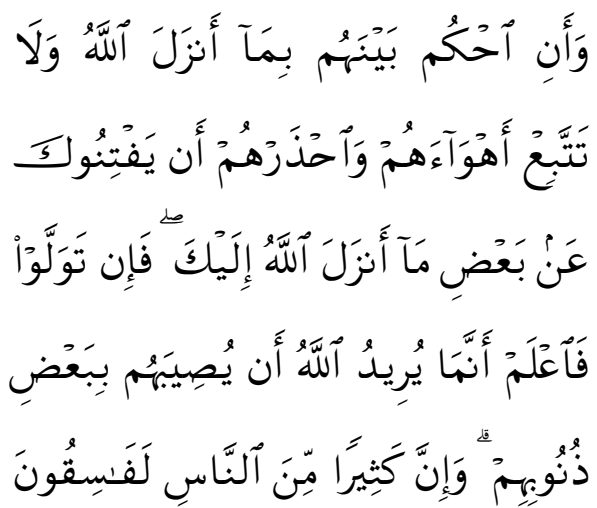

"Dan hendaklah kamu memutuskan perkara di antara mereka menurut apa yang diturunkan Allah, dan janganlah kamu mengikuti hawa nafsu mereka. dan berhati-hatilah kamu terhadap mereka, supaya mereka tidak memalingkan kamu dari sebahagian apa yang telah diturunkan Allah kepadamu. jika mereka berpaling (dari hukum yang telah diturunkan Allah), Maka ketahuilah bahwa Sesungguhnya Allah menghendaki akan menimpakan mushibah kepada mereka disebabkan sebahagian dosa-dosa mereka. dan Sesungguhnya kebanyakan manusia adalah orang-orang yang fasik". (Q.S. Al-Maidah: 49)

Ayat tersebut menjelaskan bahwa Allah menciptakan Daud sebagai khalifah di muka bumi ini supaya menghukumi di antara manusia dengan benar.

Sedangkan ayat selanjutnya menegaskan bila menghukumi manusia harus sesuai dengan dengan apa yang telah dianjurkan oleh Allah dan orang yang menghukumi tersebut adalah hakim. Dalil hadis antara lain:

إذاحكم الحاكم فاجتهد ثم اصاب فله اجران و أذاحكم فاجتهذ ثم فأخطاء فله أجر فريضة

Dari hadis dan ijma' tersebut dijelaskan tentang keutamaan ijtihad, kemuliaan ijtihad yang dilakukan dengan sungguh-sungguh baik benar atau salah akan mendapat pahala. Maksudnya seorang hakim dalam memutuskan perkara yang dihadapinya itu melalui qiyas yang mengacu kepada al-Kitab dan al-Sunah bukan berdasarkan pendapat pribadi, yang terlepas dari keduanya.

Hal ini sebagai salah satu usaha menggali hukum guna melindungi kepentingan- 
kepentingan orang-orang yang teraniaya dan untuk mernghilangkan sengketasengketa yang timbul dalam masyarakat, akibat dari luasnya wilayah Islam, seperti pada masa bani umayah khalifah hanya mengangkat qodh'i pusat dan didaerah diserahkan pada penguasa daerah hanya diberi wewenang untuk memutuskan perkara, sedangkan untuk pelaksanaan putusan oleh khalifah langsung atau oleh utusannya. Sedangkan pada masa Bani Abbasiah dibentuknya Mahkamah Agung, pembentukan hakim setiap wilayah, pembukuan dan mulainya organisasi peradilan, ${ }^{14}$ sehingga menempatkan hakim sebagi sosok yang sangat diperlukan dan mempunyai peranan penting.

Hakim sebagai pelaksana hukum-hukum Allah mempunyai kedudukan yang sangat penting sekaligus mempunyai beban yang yang sangat berat. Dipandang penting karena melalui hakim akan tercipta produk-produk hukum baik melalui ijtihad yang sangat dianjurkan sebagai

14 Tengku Muhammad Hasbi ash Shidiqi.,hlm. 30-32 keahlian hakim yang diharapkan dengan produk tersebut segala bentuk kezaliman yang terjadi dapat tercegah dan diminimalisir sehingga ketentraman masyarakat terjamin. Dari tugas hakim ini menunjukkan posisi hakim sangat penting sebagai unsur badan peradilan. Dari penjelasan dasar hakim di atas menempatkan Hakim sebagai salah satu unsur peradilan yang dipandang penting dalam menyelesaikan perkara yang diperselisihkan antara sesama, oleh sebab itu harus didukung oleh pengetahuan dan kemampuan yang professional dengan syarat-syarat yang umum dan khusus yang di tentukan oleh oleh Mahkamah Agung atas kekuasaan kehakiman yang diatur oleh undang-undang tersendiri, terkecuali Mahkamah Konstitusi yang kekuasaan dan kewenangannya oleh Mahkamah Konstitusi.

Adapun syarat menjadi hakim secara umum adalah:
a. Warga Negara Indonesia
b. Bertaqwa Kepada Tuhan Yang Maha Esa
c. Setia Pada Pancasila dan Undang-undang 
d. Bukan anggota organisasi terlarang

e. Pegawai Negeri

f. Sarjana hukum

g. Berumur serendah-rendahnya 25 tahun

h. Berwibawa, jujur, adil dan berkelakuan baik

i. Bukan bekas anggota organisasi terlarang Partai Komunis Indonesia, termasuk organisasi massanya atau bukan seorang yang terlibat langsung ataupun tak langsung dalam "Gerakan Kontra Revolusi G.30.S/PKI", atau organisasi terlarang lainnya.

Kesembilan persyaratan itu menunjukkan suatu perpaduan antara produk pemikiran fuqaha dengan ketentuan yang berlaku secara umum bagi hakim pada pengadilan tingkat pertama. Secara umum persyaratan hakim pada semua badan peradilan adalah sama. Hal itu terlihat dalam tujuh dari sembilan persyaratan, yang juga harus dipenuhi oleh calon hakim pada Pengadilan Negeri dan Pengadilan Tata Usaha Negara. Sedangkan syarat kedua dan ketujuh hanya berlaku bagi calon hakim pada pengadilan dan lingkungan
Peradilan Agama, yang erat hubungannya dengan produk pemikiran fuqaha. Hal itu konsisten dengan kekhususan badan peradilan itu di Indonesia, yang berwenang mengadili perkara perdata tertentu menurut hukum Islam di kalangan orangorang yang beragama Islam.

$$
\text { Mengenai ketentuan }
$$
khuhusnya terdapat pada masingmasing lembaga peradilan. Peradilan Agama mensyaratkan hakim harus beragama Islam dan sarjana syari'ah atau sarjana hukum yang mempunyai kehlian dalam bidang hukum Islam. Dan pada peradilan Tinggi Agama minimal berumur 40 tahun dan minimal harus 5 tahun menjadi ketua Peradilan Agama dan 15 Tahun menjadi hakim pada Peradilan Agama. ${ }^{15}$ Peradilan Tata Usaha Negara mensyaratkan sarjana hukum yang memiliki keahlian di bidang Tata Usaha Negara atau Administrasi Negara yang melaksanakan fungsi untuk menyelenggarakan urusan pemerintahan baik Pusat maupun Daerah, sedangkan pada Peradilan

${ }^{15}$ Undang-undang Nomor 7 Tahun 1989 Tentang Peradilan Agama Pasal 13 Ayat (1). Dan lihat juga Pasal Pasal 14 Ayat (1) Butir (a-c). 
Tinggi Tata Usaha Negara minimal berumur 40 tahun dan minimal harus 5 tahun menjadi ketua atau wakil Peradilan Tata Usaha Negara dan 15 Tahun menjadi hakim pada Peradilan Tata Usaha Negara. ${ }^{16}$ Pada peradilan Militer mensyaratkan hakim harus pengalaman dalam peradilan, berpangkat kapten dan berijazah sarjana hukum, dan pada Hakim Militer Tinggi minimal berpangkat Letnan Kolonel, serta pada Hakim Militer Utama minimal berpangkat kolonel dan pengalaman sebagai Hakim Militer Tinggi atau sebagai Oditur Militer Tinggi, ${ }^{17}$ Sedangkan pada Peradilan Militer ini tidak ada batasan umur yang menjadi persyaratan. Adapun Peradilan adhoc pada Peradilan Hak Azasi Manusia hakim harus mempunyai keahlian hukum, berumur minimal 45 tahun dan maksimal 65 tahun dan memiliki kepedulian di bidang hak azasi manusia, serta pada hakim ad hoc pada Mahkamah Agung minimal

16 Undang-undang Nomor 5 Tahun 1986 Tentang Tata Usaha Negara Pasal 14 Ayat (1) dan Pasal 15 Ayat (1) Butir (a-c).

17 Undang-undang Nomor 31 Tahun 1997 Tentang Peradilan Militer, Pasal 18 Butir (d dan e), Pasal 19 Butir (d), serta Pasal 20 Butir (d-e). berumur 50 tahun. $^{18}$ Sedangkan pada Mahkamah Agung atau Hakim Agung minimal umur 50 tahun dan sekurang-kurangnya 20 Tahun menjadi hakim dan sekurang-kurangnya 3 Tahun menjadi hakim tinggi. Dan apabila diangkat dari dari bukan karir yaitu dari profesi hukum atau akademisi, sekurangkurangnya telah menjalani rofesinya selama 25 Tahun, dan berijazah magister hukum. ${ }^{19}$ Dan Mahkamah Konstitusi yaitu mempunyai kewenangan pada tingkat pertama dan terakhir yang putusannya bersifat final, mensyaratkan hakim minimal berumur 40 tahun, tidak pernah dijatuhi pidana penjara berdasarkan putusan pengadilan dengan kekuatan hukum tetap yang diancam lima tahun penjara serta tidak dinyatakan pailit dan mempunyai pengalaman di bidang hukum minimal 10 Tahun, serta masa jabatan hakim Mahkamah Konstitusi ini hanya 5 Tahun. ${ }^{20}$

18 Undang-undang Nomor 26 Tahun 2000 Tentang Peradilan Hak Azasi Manusia, Pasal 29 Butir (3, 4 dan 8).

${ }^{19}$ Undang-undang Nomor 5 Tahun 2004 beserta penjelasannya Tentang Mahkamah Agung, Pasal 7 ayat (1) Butir (a dan F) dan Ayat (2) Butir (b) dan (c).

${ }^{20}$ Undang-undang Nomor 24 Tahun 2003 Tentang Mahkamah Konstitusi, Pasal 16 ayat (1) 
Adapun Cik Hasan Bisri menyatakan persyaratan tersebut termasuk kedalam dua katagori. Pertama, syarat kongkrit yaitu nomor 1-8, kecuali nomor 3 dan 8. kedua, sebagai syarat Abstrak yaitu : Bertaqwa, Adil, jujur dan setia. $^{21}$

Sedangkam Imam

Mawardi menambahkan bahwa hakim harus diketahui identitasnya, harus memahami tugas atas pekerjaanya, menyebut wewenangnya dan wilayah (Negara atau Propinsi). ${ }^{22}$

Sedangkan dalam literatur Islam atau fiqih ada beberapa persyaratan yang menjadi persamaan dan perbedaan, persamaannya hakim harus berakal, Islam, adil, berpengetahuan baik dalam pokok hukum agama dan cabangcabangnya, sehat pendengaran, penglihatan dan ucapan dan

Butir (c-f), dan lihat juga kewengan Mahkamah Konstitusi yang bersifat final dalam Undangundang Nomor 4 Tahun 2004 Tentang Pokokpokok Kekuasaan Kehakiman, Pasal 12 ayat (1) Butir (a-d) dan Ayat (2), serta Pasal 22.

21 M.Yahya Harahap, Kedudukan Kewenangan Dan Acara Peradilan Agama, cet. ke-1, (Jakarta: Pustaka Kartini: 1993), hlm. 112.

${ }^{22}$ Imam Mawardi, Hukum Tata Negara Dan Kepemimpinan Dalam Takaran Islam, cet. ke-1, (Jakarta: Gema Insani Press, Tahun 2000), hlm. 142-143. merdeka bukan hamba sahaya. ${ }^{23}$ Adapun perbedaannya adalah pada fiqih Islam disyaratkan hakim laki-laki dan tidak boleh perempuan yang terjadi khilafiyah diantara para ulama dari empat mazhab kecuali Abu Hanifah membolehkan selain dalam urusan hadd dan qisas, karena kesaksian dalam dua hal tersebut tidak dapat diterima. ${ }^{24}$

Persyaratan-persyaratan

tersebut merupakan persyaratan pada masa dahulu dikarenakan luasnya wilayah Islam dan banyaknya permasalahan yang muncul sehingga menjadi komplek sedangkan lembaga peradilan masih sangat sedikit, namun dalam kontek sekarang peradilan yang yang sudah merata dan laju kehidupan yang semakin maju sehingga persyaratanpersyaratan itu menjadi dikontekkan secara umum untuk lebih mewadahi pluralitas yang ada, kecuali dalam peradilan agama yang memakai azas personalitas keIslaman sebagai

${ }^{23}$ Sulaiman Rasjid, Fiqih Islam, cet. ke-27, ( Bandung: Sinar Baru Algesindo, 1994), hlm. 487.

24 M.Yahya Harahap, Kedudukan Kewenangan Dan Acara Peradilan Agama, cet. ke-1, (Jakarta: Pustaka Kartini : 1993), hlm. 3543. 
lembaga peradilan khuhus dari lembaga peradilan yang lainnya.

Dengan berbagai macam syarat tersebut diharapkan hakim dapat bermoral tinggi dan tidak boleh melakukan perbuatan tercela, melanggar sumpah jabatan atau melanggar larangan seperti menjadi pengusaha atau penasehat hukum, Karena syarat tersebut termasuk dalam ajaran yang menuntut moral dan tanggungjawab sebagai seorang hakim setelah disumpah sesuai agamanya masing-masing.

Adapun lafal sumpah dan janjinya sebagai berikut:

Sumpah:

"Demi Allah saya bersumpah bahwa saya akan memenuhi kewajiban hakim dengan sebaikbaiknya dan seadil-adilnya, memegang teguh Undang-Undang Dasar Negara Republik Indonesia Tahun 1945, dan menjalankan segala peraturan perundangundangan dengan seluruslurusnya menurut UndangUndang Dasar Negara Republik Indonesia tahun 1945, serta berbakti kepada nusa dan bangsa."

Janji:

"Saya berjanji bahwa saya dengan sungguh-sungguh akan memenuhi kewajiban hakim dengan sebaikbaiknya dan seadil-adilnya, memegang teguh Undang-Undang Dasar Negara Republik Indonesia Tahun 1945, dan menjalankan segala peraturan perundangundangan dengan seluruslurusnya menurut UndangUndang Dasar Negara Republik Indonesia Tahun 1945, serta berbakti kepada nusa dan bangsa." 25

Maka jika seorang hakim melanggar maka dapat diberhentikan secara tidak hormat oleh Presiden dengan terlebih dahulu diberi kesempatan untuk membela diri.

\section{Tanggung Jawab Hakim}

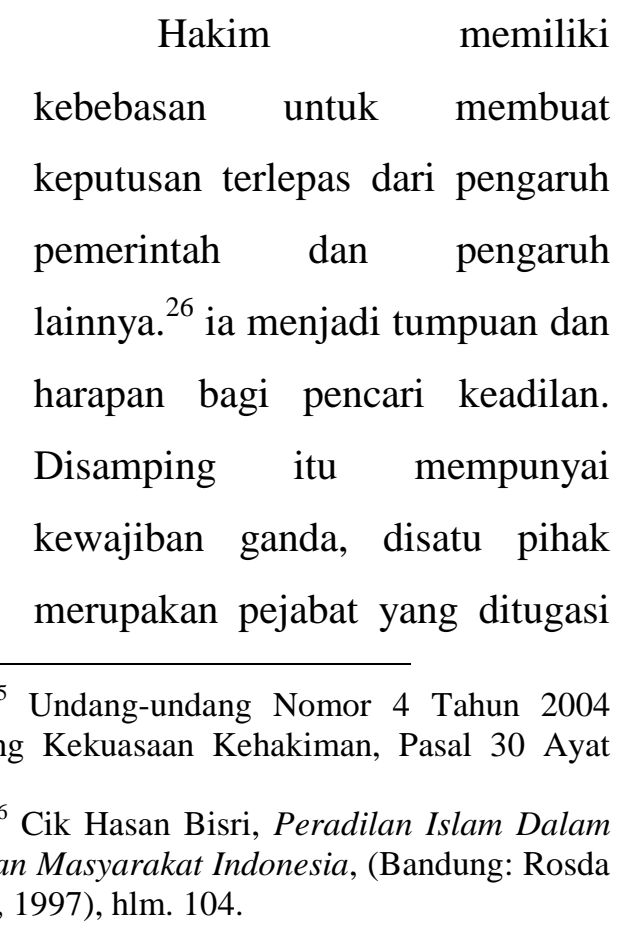


menerapkan hukum (izhar alhukum) terhadap perkara yang kongkrit baik terhadap hukum tertulis maupun tidak tertulis, dilain pihak sebagai penegak hukum dan keadilan dituntut untuk dapat menggali, memahami, nilai-nilai yang ada dalam masyarakat. Secara makro dituntut untuk memahami rasa hukum yang hidup di dalam masyarakat.

\section{Undang-undang}

disebutkan tugas pengadilan adalah: tidak boleh menolak untuk memeriksa, mengadili dan memutus suatu perkara yang diajukan dengan dalih bahwa hukum tidak ada atau kurang jelas, melainkan wajib untuk memeriksa dan mengadilinya. ${ }^{27}$ Artinya hakim sebagai unsur pengadilan wajib menggali, mengikuti dan memahami nilainilai hukum dan rasa keadilan yang hidup dalam masyarakat. ${ }^{28}$

Mengkonstatir yaitu yang dituangkan dalam Berita Acara

27 Undang-undang Nomor 4 Tahun 2004 Tentang Kekuasaan Kehakiman, Pasal 16 Ayat (1) dan lihat Undang-undang Nomor 7 Tahun 1989 Tentang Pengadilan Agama Pasal 56 ayat (1)

28 Undang-undang Nomor 4 Tahun 2004 Tentang Kekuasaan Kehakiman, Pasal 28 Ayat (1)
Persidangan dan dalam duduknya perkara pada putusan hakim. Mengkonstatir ini dilakukan dengan terlebih dahulu melihat pokok perkara dan kemudian mengakui atau membenarkan atas peristiwa yang diajukan, tetapi sebelumnya telah diadakan pembuktian terlebih dahulu.

Mengkualifisir yaitu yang dituangkan dalam pertimbangan hukum dalam surat putusan. Ini merupakan suatu penilaian terhadap peristiwa atas buktibukti, fakta-fakta peristiwa atau fakta hukum dan menemukan hukumnya.

Mengkonstituir yaitu yang dituangkan dalam surat putusan. Tahap tiga ini merupakan penetapan hukum atau merupakan pemberian konstitusi terhadap perkara.

Tahapan-tahapan tersebut menjadikan hakim dituntut untuk jeli dan hati-hati untuk memberikan keputusan sekaligus menemukan hukumnya, karena pada dasarnya hakim dianggap mengetahui hukum dan dapat mengambil keputusan berdasarkan ilmu pengetahuan dan keyakinannya sesuai dengan 
doktrin Curia Ius Novit. ${ }^{29}$ Karena dalam undang-undang dijelaskan bahwa hakim tidak boleh menolak perkara yang diajukan kepadanya untuk diperiksa dan diputus, dengan alasan bahwa hukum yang ada tidak ada atau kurang jelas. ${ }^{30}$

Sedangkan fungsi hakim adalah menegakkan kebenaran sesungguhnya dari apa yang dikemukakan dan dituntut oleh para pihak tanpa melebihi atau menguranginya terutama yang berkaitan dengan perkara perdata, sedangkan dalam perkara pidana mencari kebenaran sesungguhnya secara mutlak tidak terbatas pada apa yang telah dilakukan oleh terdakwa, melainkan dari itu harus diselidiki dari latar belakang perbuatan terdakwa. ${ }^{31}$ Artinya hakim mengejar kebenaran materil secara mutlak dan tuntas.

Di sini terlihat intelektualitas hakim yang akan teruji dengan dikerahkannya segenap kemampuan dan bekal ilmu pengetahuan yang mereka miliki, yang semua itu akan

29 Abdul Kadir Muhammad, Hukum Acara Perdata Indonesia, (Bandung: Citra Aditya Bakti, 1992), hlm. 37.

${ }^{30}$ Undang-undang Nomor 07 Tahun 1989 Tentang Peradilan Agama Pasal 56 Ayat (1).

${ }^{31}$ Abdul Kadir Muhammad, Hukum Acara, hlm. 38 . terlihat pada proses pemeriksaan perkara apakah masih terdapat pelanggaran-pelanggaran dalam teknis yustisial atau tidak.

Tugas hakim adalah melaksanakan semua tugas yang menjadi tanggung jawabnya untuk memberikan kepastian hukum semua perkara yang masuk baik perkara tersebut telah di atur dalam Undang-undang maupun yang tidak terdapat ketentuannya. Disini terlihat dalam menjalankan tanggung jawabnya hakim harus bersifat obyektif, karena merupakan fungsionaris yang ditunjuk undang-undang untuk memeriksa dan mengadili perkara, dengan penilaian yang obyektif pula karena harus berdiri di atas kedua belah pihak yang berperkara dan tidak boleh memihak salah satu pihak. ${ }^{32}$

Tugas hakim adalah mempertahankan tata hukum, menetapkan apa yang ditentukan oleh hukum dalam suatu perkara. Dengan demikian yang menjadi tugas pokoknya adalah menerima, memeriksa, dan mengadili serta

${ }^{32}$ C.S.T. Kansil dan Christine S.T. Kansil, Pokok-Pokok Etika Profesi Hukum, (Jakarta: Pradnya Pramita, 1996), hlm. 46-48. 
menyelasaikan setiap perkara yang diajukan kepadanya.

Dari banyaknya masalah yang ada, tidak semuanya ada peraturan perundangundangannya yang mengatur masalah tersebut. Untuk mengatasi masalah hal ini hakim tidak perlu untuk selalu berpegang pada peraturan-peraturan yang tertulis saja, dalam keadaan demikian tepatlah apabila hakim diberi kebebasan untuk mengisi kekosongan hukum. Untuk mengatasi masalah tersebut hakim dapat menyelesaikannya dengan memperhatikan hukum yang hidup dalam masyarakat atau yang dikenal dengan hukum adat. Sehingga dengan demikian tidak akan timbul istilah yang dikenal dengan sebutan kekosongan hukum. Kewenangan hakim untuk melakukan hal demikian ini sesuai pula dengan apa yang telah ditentukan dalam pasal 16 ayat (1) UU No. 4 Tahun 2004.

Dengan melihat kenyataan di atas, maka tampak jelas bahwa dalam hal ini hakim harus aktif dari permulaan sampai akhir proses, bahkan sebelum proses dimulai, yaitu pada waktu penggugat mengajukan gugatan, hakim telah memberikan pertolongan kepadanya. Sedangkan setelah proses berakhir, hakim memimpin eksekusi.

Aktifnya hakim dapat dilihat dari misalnya dengan adanya usaha dari hakim untuk mendamaikan dari kedua belah pihak. Bentuk yang lain misalnya, tindakan hakim untuk memberikan penerangan selayaknya kepada para pihak yang berperkara tentang upayaupaya hukum apa yang dapat mereka lakukan, atau tentang pengajuan alat-alat bukti, sehingga dengan demikian pemeriksaan dapat berjalan dengan lancar.

Selain bersifat aktif, hakim bersifat pula pasif, dalam arti bahwa ruang lingkup atau luas pokok sengketa yang diajukan kepada hakim untuk diperiksa pada asasnya ditentukan oleh para pihak yang berperkara dan bukan oleh hakim. Hakim hanya membantu para pencari keadilan dan mengatasi segala hambatan dan rintangan untuk dapat tercapainya keadilan. Dalam hal ini, para pihak dapat secara bebas mengakhiri sengketa yang telah 
diajukan ke muka pengadilan, sedang hakim tidak dapat menghalang-halanginya, hal ini dapat dilakukan dengan jalan perdamaian atau pencabutan gugatan. Dengan demikian hakim tidak menentukan luas dari pokok sengketa, yang berarti hakim tidak boleh menambah atau menguranginya.

Dari sini dapat disimpulkan, bahwa hakim bersifat aktif kalau ditinjau dari segi demi kelancaran persidangan, sedangkan hakim bersifat pasif kalau ditinjau dari segi luasnya tuntutan.

Tugas hakim pengadilan agama di dalam mewujudkan keadilan berdasarkan Ketuhanan Yang Maha Esa, bukan sekedar berperan memantapkan kepastian hukum, melainkan juga keadilan. ${ }^{33}$

Kedudukan hakim adalah sebagai pejabat yang melakukan kekuasaan kehakiman yang diatur dalam undang-undang. ${ }^{34}$ Hakim juga harus memiliki integritas dan kepribadian yang tidak tercela,

33 Hal ini secara resmi tercantum dalam pasal 4 ayat (1) UU No. 4 Tahun 2004 tentang Ketentuan-ketentuan Pokok Kekuasaan Kehakiman: "Demi keadilan berdasarkan Ketuhanan Yang Maha Esa".

${ }^{34}$ UU No. 4 Tahun 2004 tentang Kekuasaan Kehakiman, (Surabaya: Karina, 2004), hlm. 35. jujur, adil, professional, dan berpengalaman dalam bidang hukum, dan bagi soerang hakim dituntut dalam menjalankan tugas dan fungsinya, hakim wajib menjaga kemandirian peradilan.

\section{Peranan Peradilan}

\section{Pengertian Peranan}

Peranan adalah suatu sistem atau kaidah-kaidah yang berisikan potokan-patokan perilaku, pada kedudukan-kedudukan tertentu di dalam masyarakat, kedudukan tersebut dimiliki oleh pribadi atau kelompok yang peranannya memegang perananan tersebut, dapat sesuai atau mungkin berlawanan dengan apa yang ditentukan di dalam kaidahkaidah. ${ }^{35}$

Suatu peranan dari induvidu atau kelompok dapat dijabarkan dalam beberapa bagian, yaitu:

a. Peranan yang ideal yaitu peranan yang dijalankan oleh indivudu atau kelompok sesuai dengan ketentuan-ketentuan yang ditetapkan.

b. Peranan yang seharusnya yaitu peranan yang memang harusnya dijalankan oleh

35 Soerjono Soekanto, Pokok-pokok Sosiologi Hukum, Jakarta: Grafindo Persada, 2003, Hlm. 193 
individu atau kelompok sesuai dengan kedudukannya.

c. Peranan yang dianggap diri sendiri yaitu peranan yang dijalankan oleh diri sendiri karena kedudukannya dilakukan untuk kepentingannya.

d. Peranan yang sebenarnya dilakukan yaitu peranan dimana individu mempunyai kedudukan dan benar telah menjalankan peranan sesuai dengan kedudukannya. ${ }^{36}$

Berkaitan dengan penegakan hukum, perananan yang ideal dan perananan yang sebenarnya adalah memang perananan yang dikehendaki dan diharapkan oleh hukum ditetapkan oleh hukum ditetapkan oleh Undang-Undang. Sedangkan peranan yang dianggap diri sendiri dan peranan yang sebenarnya telah dilakukan peranan yang mempertimbangkan antara kehendak hukum yang tertulis dengan kenyataan yang ada.
Berdasarkan teori tersebut Soerjono Soekanto mengambil pengertian bahwa:

a. Perananan yang ditetapkan sebelumnya disebut sebagai perananan normatif, dalam penegakan hukum secara total enforcement, yaitu penegakan hukum yang bersumber pada substansi (substansi of the criminal law)

b. Perananan ideal dapat diterjemahkan sebagai perananan yang diharapkan dilakukan oleh pemegang perananan tersebut.

c. Interaksi kedua perananan yang telah diuraikan diatas, akan membentuk perananan yang faktual yang dimiliki satuan Lembaga Bantuan Hukum.

Peranan yang sebenarnya dilakukan dinamakan role performance atau role playing. ${ }^{37}$ Peranan dalam hal ini adalah tindakan atau perbuatan yang diharapkan oleh seseorang atau kelompok kepada seseorang atau kelompok yang berdasarkan kedudukannya dapat memberikan

37 Poerwadarminta, W.J.S., Kamus Umum Bahasa Indonesia, Jakarta: PT.Balai Pustaka, 1995, hlm751 
sebuah pengaruh terhadap

lingkungan tersebut.

Berdasarkan uraian di atas dapat diketahui bahwa peranan merupakan seperangkat norma atau aturan yang berisi kewajiban yang dimiliki oleh seseorang dalam menjalankan dan melaksanakan tugas serta kedudukannya pada tingkat social masyarakat. Perananan yang melekat pada diri seseorang harus dibedakan dengan posisi dalam pergaulan masyarakat. Posisi seseorang dalam masyarakat merupakan unsur statis yang menunjukkan tepat individu dalam masyarakat. Perananan lebih banyak menunjuk pada fungsi, penyesuaian diri, dan sebagai suatu proses. Jadi, seseorang menduduki suatu posisi dalam masyarakat serta menjalankan suatu perananan...

\section{Putusan Hakim Yang}

\section{Berkeadilan}

Peradilan Administrasi Negara adalah salah satu pilar penting dalam pengejawantahan prinsip-prinsip negara hukum yang memberikan jaminan perlindungan hukum yang cukup terhadap kekuasaan negara yang besar sebagai konsekwensi

welfare state. Dalam rangka memberikan perlindungan tersebut dibutuhkan satu media atau institusi keadilan yang dapat digunakan sebagai akses bagi masyarakat untuk mendapatkan keadilan tersebut. Lembaga pengadilan ini secara simbolik telah menjadi wujud dari pemberlakuan hukum dan keadilan secara nyata. Salah satunya adalah Pengadilan Tata Usaha Negara yang memberikan akses keadilan bagi para pencari keadilan di bidang tata usaha negara. ${ }^{38}$

Penegakan hukum administrasi dilakukan oleh hakim Pengadilan Tata Usaha Negara. Tugas pokok hakim Pengadilan Tata Usaha Negara adalah menerima, memeriksa, mengadili, memutuskan dan menyelesaikan setiap sengketa tata usaha negara yang diajukan kepadanya. Namun kadangkala fungsi lembaga Peradilan Tata Usaha Negara dalam rangka melindungi hak-hak

38 Yos Johan Utama, Menggugat Fungsi Peradilan Tata Usaha Negara Sebagai Salah Satu AksesWarga Negara Untuk Mendapatkan Keadilan Dalam Perkara Administrasi Negara (Suatu Studi Kritis Terhadap Penggunaan AsasAsas Hukum Administrasi dalam Peradilan Administrasi, dalam Jurnal Ilmu Hukum Volume 10 Nomor 1 Maret 2007, Universitas Muhammadiyah Surakarta, Surakarta, hlm. 26 
masyarakat seringkali harus berhadapan dengan diskursus pilihan antara keadilan dan kepastian hukum. Tidak jarang terjadi kepastian hukum bertentangan dengan keadilan. Sebagaimana dikemukakan Sudikno Mertokusumo ${ }^{39}$ bahwa hukum demikian bunyinya, maka harus dijalankan (kepastian hukum) tapi kalau dijalankan dalam keadaan tertentu akan dirasakan tidak adil lex dura sed tamen scripta hukum itu kejam, tetapi demikianlah bunyinya.

Hakim dalam semua tingkatan menduduki posisi sentral dalam proses peradilan. Dalam posisi yang sentral itulah diharapkan dapat menegakkan hukum dan keadilan. Persoalan yang perlu diselesaikan oleh hakim adalah bagaimana keadilan yang bersifat abstrak yang berisi nilai-nilai tertentu dapat dijadikan pegangan dalam penerapannya. Pekerjaan untuk mewujudkan ide dan konsep keadilan ke dalam bentuk-bentuk konkrit sehingga diterima oleh masyarakat, merupakan pekerjaan para penegak hukum terutama para hakim. Esmi Warassih ${ }^{40}$ mengemukakan bahwa hakim diharapkan memiliki kemampuan menterjemahkan nilai-nilai keadilan dalam persoalanpersoalan yang dihadapkan kepadanya melalui putusanputusannya.

Penerapan konsep abstrak ke dalam rumusan-rumusan hukum dan selanjutnya bagaimana penerapannya ke dalam masyarakat sering menimbulkan persoalan khususnya persoalan yang menyangkut keadilan karena hukum merupakan makna simbolik yang memerlukan interpretasi lebih lanjut. Oleh karena itu persoalan keadilan pun yang dirumuskan orang tergantung dari sisi mana melihatnya. Sebagaimana dicontohkan keadilan di bidang kekeluargaan tidak akan sama dengan masalah keadilan di bidang pidana, bidang ketatanegaraan dan seterusnya, sehingga wajah keadilan bersifat dimensional. Dalam negara Pancasila, konsep keadilan hukum yang multidimensional tersebut 
dicakup dengan satu istilah yaitu

Demi Keadilan berdasarkan

Ketuhanan Yang Maha Esa.

Keadilan disini memiliki arti yang sempurna karena tidak hanya menyangkut pembagian sumber daya saja tetapi harus merujuk pada persoalan akhlak. ${ }^{41}$

Hanya hakim yang baik yang diharapkan dapat menghasilkan putusan yang berkualitas. Putusan hakim yang berkualitas merupakan cerminan kepiawaian dan kemampuan hakim di dalam memutus perkara. Salah satu aspek yang harus dimiliki seorang hakim dalam menjalankan tugas, fungsi dan wewenangnya adalah profesionalisme sebagaimana dikemukakan Roscoe Pond bahwa tidak berjalannya penegakan hukum sebagaimana yang diharapkan, lebih banyak disebabkan karena faktor sumber daya manusia, bukan karena faktor hukum itu sendiri. Hal ini sejalan dengan Beijing Statement of Principls of the Independence of the Judiciary in the Law Asia Region yang menetapkan bahwa sikap profesionalisme hakim

\footnotetext{
${ }^{41}$ Esmi Warassih......, hlm. 19
}

dibangun oleh tiga pilar utama yaitu nilai-nilai kecakapan (competence), kejujuran (integrity) dan kemerdekaan (independence) yang dipergunakan menegakkan kebenaran dan keadilan. Selanjutnya profesionalisme hakim diukur antara lain dari mutu putusannya. ${ }^{42}$

Profesionalisme hakim dilihat dari sudut putusan yang dibuat akan dilihat dengan melihat beberapa kriteria yaitu: Pertama, pengetahuan, penguasaan serta pengembangan secara sistematik, metodik dan rasional asas-asas, kaidah-kaidah, dan/atau aturanaturan hukum baik tingkat lokal, nasional, transnasional maupun internasional serta pada tataran hukum dasar atau bidang-bidang hukum pada sektorsektor kehidupan manusia dalam

42 Sebagaimana dikemukakan oleh Mustafa Abdullah bahwa terdapat banyak pandangan tentang

kiteria hakim baik antara lain, memiliki kemampuan hukum (legal skill), berpengalaman yang

memadai, memiliki integritas, memiliki kesehatan yang baik, mncerminkan keterwakilan masyarakat, memiliki nalar yang baik, memiliki visi yang luas, memiliki kemampuan berbahasa dan menulis, mampu menegakkan hukum negara dan bertindak independen dan imparsial dan memiliki kemampun administratif dan efisien dalam Laporan Penelitian Putusan Hakim Tahun 2007, Tersedia di http://komisiyudisial.go.id 
putusan-putusan yang dibuat.

Kedua: kemampuan berpikir yuridik dari hakim yaitu kemampuan menalar (reasoning) dalam kerangka tatanan hukum yang berlaku (baik dalam tataran lokal, nasional, transnasional maupun internasional) untuk mengidentifikasi hak dan kewajiban manusia di dalam pergaulan hidupnya dengan mengacu pada upaya mewujudkan cita-hukum (rechtsidee) yang mencakup idea tentang kepastian hukum predikbilitas kemanfaatan sosial dan keadilan yang harus diwujudkan di dalam masyarakat melalui kaidah-kaidah hukum. Ketiga: kemahiran yuridik mencakup keterampilan, atau kemahiran dalam menelusuri dan menemukan bahan-bahan hukum (legal materials), kemampuan untuk menangani bahan-bahan hukum yang ada (penggunaan doktrin dan yurisprudensi).

Keempat, kesadaran serta komitmen profesional yang mencakup upaya penumbuhan sikap, kepekaan dan kesadaran etik profesional khususnya berkenaan dengan pembebanan profesi hukum sebagai profesi yang berorientasi pada upaya mewujudkan keadilan dalam masyarakat serta profesi hukum sebagai profesi yang terhormat "officium nobile". 43

Dalam rangka hakim membuat putusan yang berkualitas sebagaimana terurai diatas, pintu masuknya tetap melalui "teks" dalam hal ini undang-undang atau kodifikasi sebuah regulasi. Namun hal tersebut hanyalah starting point bagi hukum untuk mengelaborasi suatu perkara sehingga dapat ditempatkan pada "konteksnya". Penempatan "teks pada konteks" atau sebaliknya penyandingan "konteks ke dalam teks" secara sederhana dalam persidangan disebut sebagai proses pembuktian perkara dengan instrumen alat buktinya. Oleh karena sebuah regulasi hanya sebagai starting point maka kewajiban hakim pada tahap berikutnya adalah mengintepretasikan regulasi tersebut dengan tidak menutup kemungkinan terserapnya nilainilai dan aspirasi serta opini yang berkembang dalam masyarakat. The laws in books akan

\footnotetext{
${ }^{43}$ Esmi Warassih,....... hlm. 9
} 
bersinggungan dengan the living law dimana putusan hakim ikut serta menentukan isi dan arah perkembangan hukum Indonesia. Hakim dapat menggali dan menemukan nilai-nilai hukum yang baik dan benar sesuai dengan Pancasila dan "according to the law of civilized nation...". 44

Persoalan keadilan ${ }^{45}$ sendiri tidak akan pernah selesai secara tuntas dibicarakan orang, bahkan persoalan keadilan semakin mencuat seiring dengan perkembangan masyarakat itu sendiri karena tuntutan dan kepentingan yang berbeda bahkan bertentangan satu sama lain. Adapun perbedaan interpretasi dan pemahaman terhadap norma hukum disebabkan perbedaan budaya hukum para pelaku (stakeholders) baik penegak hukum, birokrat maupun warga masyarakat. Keadilan memiliki

44 Jimly Maruli, Dicari: Putusan Yang Progresif, Majalah Hukum Varia Peradilan, No. 293 April 2010, hlm. 81

45 Keadilan sebenarnya merupakan suatu keadaan keseimbangan, keserasian dan keselarasan yang

membawa ketenteraman di dalam hati orang yang apabila diganggu akan mengakibatkan kegoncangan, Sukarno Aburaera, Menakar Keadilan Dalam Hukum, Makalah Pidato pada upacara pengukuhan Jabatan Guru Besar Tetap dalam bidang Imu Huum pada Fakultas Hukum Universitas Hasanuddin pada hari Senin 6 November 2006 di Makasar, hlm. 56 ragam makna sebagaimana diuraikan M. Quraish Shihab ${ }^{46}$ diantaranya : (1) adil dalam arti sama. Persamaan yang dimaksud adalah persamaan dalam hak (2) adil dalam arti seimbang. Keseimbangan ditemukan pada suatu kelompok yang didalamnya terdapat beragam bagian yang menuju satu tujuan tertentu, selama syarat dan kadar tertentu terpenuhi oleh setiap bagian (3) Perhatian terhadap hak-hak individu dan memberikan hak-hak itu kepada setiap pemiliknya. Pengertian ini didefinisikan dengan menempatkan sesuatu pada tempatnya atau memberi pihak lain haknya melalaui jalan yang terdekat (4) Adil yang dinisbatkan kepada ilahi. Adil disini berarti memelihara kewajaran atas berlanjutnya eksistensi, tidak mencegah kelanjutan eksistensi dan perolehan rahmat sewaktu terdapat banyak kemungkinan untuk itu.

\section{Kesimpulan}

${ }^{46}$ M. Quraish Shihab, Wawasan Al-Quran Tafsir Tematik Atas Pelbagai Persoalan Umat, ctk. Kedua, (Bandung: Mizan, 2013), hlm. 152 
Tentang tugas dan wewenang hakim sebagai penegak hukum dengan tunduk pada bunyi undangundang (keadilan prosedural) dan tugasnya sebagai penegak keadilan meski harus keluar dari ketentuan undangundang (keadilan substantif), merupakan isu klasik. Sebab pada kenyataannya, kini, sudah tidak ada lagi garis antara tradisi civil law yang menjadikan hakim hanya sebagai corong undang-undang dan tradisi common law yang menjadi hakim sebagai pembuat keadilan hukum meski harus melanggar undangundang. Keduanya dianggap sebagai kebutuhan yang saling melengkapi. Berdasar UUD 1945 hasil amandemen, di Indonesia kedua hal itu diletakkan pada posisi sama kuat. Pasal 24 ayat (1) menyebutkan, kekuasaan kehakiman merupakan kekuasaan yang merdeka untuk menyelenggarakan peradilan guna menegakkan "hukum" dan "keadilan". Pasal 28D ayat (1) juga menegaskan, setiap orang berhak atas pengakuan, jaminan, perlindungan, dan "kepastian hukum yang adil". Jadi, tekanannya bukan pada kepastian hukum saja, tetapi kepastian hukum yang adil. Memperhatikan wewenang hakim yang telah diuraikan diatas, tampak jelas bagi siapapun urgensi kedudukan hakim pengadilan dalam menegakkan kebenaran dan keadilan, betapa besar harapan masyarakat terutama pencari keadilan akan tegaknya kebenaran dan keadilan. Mengingat begitu penting kedudukan hakim pengadilan bagi penegakan kebenaran dan keadilan, dan begitu tinggi harapan masyarakat bagi tegaknya kebenaran dan keadilan, maka sangat mudah dipahami jika masyarakat akan kecewa manakala hakim pengadilan tidak mampu melaksanakn tugas dengan baik, kekecewaan masyarakat pencari keadilan terhadap putusan hakim pengadilan yang dianggap tidak adil.

\section{DAFTAR PUSTAKA}

Bisri, Cik Hasan, Peradilan Agama di Indonesia, Cet. ke-2 (Jakarta: PT Raja Grafindo Persada, 1998),

Bisri, Cik Hasan, Peradilan Islam Dalam Tatanan Masyarakat Indonesia, (Bandung: Rosda Karya, 1997),

Harahap, M.Yahya, Kedudukan Kewenangan Dan Acara Peradilan Agama, cet. ke-1, (Jakarta: Pustaka Kartini: 1993),

Hasbi Ash Sidiqi, Tengku Muhammad, Peradilan dan Hukum Acara Islam cet. ke-1, Semarang : PT Pustaka Rizki Putera, 1997),

Kansil, C.S.T. dan Christine S.T. Kansil, Pokok-Pokok Etika Profesi Hukum, (Jakarta: Pradnya Pramita, 1996),

Maruli, Jimly, Dicari: Putusan Yang Progresif, Majalah Hukum Varia Peradilan, No. 293 April 2010 
Mawardi, Imam, Hukum Tata Negara Dan Kepemimpinan Dalam Takaran Islam, cet. ke-1, (Jakarta: Gema Insani Press,Tahun 2000),

Mertokusumo, Sudikno, "M etode Penemuan Hukum“" (Yogyakarta:UII Press, 2007),

Muhammad, Abdul Kadir, Hukum Acara Perdata Indonesia, (Bandung: Citra Aditya Bakti, 1992),

Poerwadarminta, W.J.S., Kamus Umum Bahasa Indonesia, Jakarta: PT.Balai Pustaka, 1995, 1

Putusan Hakim Tahun 2007, Tersedia di http://komisiyudisial.go.id

Rasjid, Sulaiman, Fiqih Islam, cet. ke-27, ( Bandung: Sinar Baru Algesindo, 1994),

Rifai, Ahmad, Penemuan Hukum oleh Hakim dalam Perspektif Hukum Progresif , (Jakarta:Sinar Grafika, 2010),

Madkur, Muhammad Salam, Al-Qada Fil Islam, (Ttp : tt)

Shihab, M. Quraish, Wawasan Al-Quran Tafsir Tematik Atas Pelbagai Persoalan Umat, cet. Kedua,(Jakarta : Mizan :2001)

Soekanto, Soerjono, Faktor-Faktor yang Mempengaruhi Penegakan Hukum, Jakarta: CV. Rajawali, 1983,

Soekanto, Soerjono, Pokok-pokok Sosiologi Hukum, Jakarta: Grafindo Persada, 2003,

Utama, Yos Johan, Menggugat Fungsi Peradilan Tata Usaha Negara Sebagai Salah Satu Akses Warga Negara Untuk Mendapatkan Keadilan Dalam Perkara Administrasi Negara (Suatu Studi Kritis Terhadap Penggunaan AsasAsas Hukum Administrasi dalam Peradilan Administrasi, dalam Jurnal Ilmu Hukum Volume 10 Nomor 1 Maret 2007, Universitas Muhammadiyah Surakarta, Surakarta,
PERATURAN UNDANGAN

PERUNDANG-

Undang-undang No.48 Tahun 2009 tentang Kekuasaan Kehakiman

Undang-undang Nomor 7 Tahun 1989 Tentang Peradilan Agama

Undang-undang Nomor 24 Tahun 2003 Tentang Mahkamah Konstitusi,

Undang-undang Nomor 26 Tahun 2000 Tentang Peradilan Hak Azasi Manusia,

Undang-undang Nomor 31 Tahun 1997 Tentang Peradilan Militer,

Undang-undang Nomor 4 Tahun 2004 Tentang Pokok-pokok Kekuasaan Kehakiman

Undang-undang Nomor 5 Tahun 1986 Tentang Tata Usaha 